\title{
Ekolojik Farkındalığın Çevre Dostu Rekreasyon Davranışına Etkisi: Turizm Eğitimi Alan Öğrenciler Üzerine Bir Araştırma*
}

\section{Effects of Environmental Awareness on Environment-Friendly Recreation Behavior: A Research on Students Who Have Tourism Education}

\author{
Yrd. Doç. Dr. Üzeyir KEMENT \\ Bingöl Üniversitesi \\ Sosyal Bilimler MYO \\ E-posta: ukement@bingol.edu.tr \\ Orcid Id: 0000-0002-3190-9079
}

\author{
Arş. Gör. Barış DEMiRci \\ Eskişehir Osmangazi Üniversitesi \\ Turizm Fakültesi \\ E-posta: bdemirci@ogu.edu.tr \\ Orcid Id: 0000-0002-1247-1841
}

\section{Öz}

$\mathrm{Bu}$ araştırmanın amacı, turizm eğitimi alan öğrencilerin ekolojik farkındalıklarının, çevre dostu rekreasyon davranışlarına etkisinin belirlenmesidir. Araştırmada nicel araştırma yöntemi kullanılmış ve veri toplama tekniği olarak anket kullanılmıştır. Araştırmanın evrenini Türkiye'de yükseköğretim kurumlarında turizm eğitim alan öğrenciler oluşturmaktadır. Araştırma kapsamında 254 öğrenciye anket uygulanmış ve elde edilen veriler analize tabi tutularak yorumlanmıştır. Toplanan veriler ilgili istatistik programlarında doğrulayıcı faktör analizi, regresyon ve Anova analizleri yapılmış ve araştırmanın amacına uygun olarak yorumlanmıştır. Araştırma sonucunda turizm eğitimi alan öğrencilerin ekolojik farkındalıklarının çevre dostu rekreasyon davranışlarını olumlu yönde etkilediği belirlenmiştir. Ayrıca turizm eğitimi alan öğrencilerin okudukları bölümler ile çevre dostu rekreasyon davranışları arasında anlamlı bir farklılık olduğu tespit edilmiştir. Rekreasyon yönetimi, gastronomi ve mutfak sanatları bölümü okuyan öğrencilerin çevre dostu rekreasyon davranışlarının turizm işletmeciliği bölümüne göre daha yüksek olduğu tespit edilmiştir. Araştırmanın sonuçlarına göre turizm öğrencilerinin ekolojik farkındalıkları ile çevre dostu rekreasyon davranışlarının yüksek olduğu ortaya çıkmıştır.

Anahtar Kelimeler: Ekolojik farkındalık, Çevre dostu rekreasyon davranışı, Turizm

\begin{abstract}
The aim of this study is to determine the impact of the environmental awareness of tourism students on their environmentally-friendly recreation behavior. Quantitative research method was used in the research and survey was used as data collection technique. The university students who is educating on tourism constitute the scope of this study. 254 surveys were applied and subjected to analysis for the research. The collected data was verified by confirmatory factor analysis, regression and Anova analysis and interpreted in accordance with the objectives of the research. According to the regression analysis results, environmental awareness of tourism students has positive effect on environmentally-friendly recreation behavior. Besides, it was found that there was a significant difference between the tourism students' environmentally friendly recreation behaviors and their departments. Recreation management and gastronomy, cuisine arts students behave more environmentally friendly than tourism management students. According to the results of the research, it is possible to say that the environmental awareness and environmentally-friendly behaviors of tourism students are high.
\end{abstract}

Keywords: Environmental awareness, Environmentally friendly recreation behavior, Tourism

*Bu araştırma 28-30 Nisan 2016 yılında II. Ulusal Sürdürülebilir Turizm Kongresinde bildiri olarak sunulmuştur. 


\section{Giriş}

Yoğun tempo içerisinde çalışma ortamı, şehirleşmenin vermiş olduğu karmaşa gibi bir takım sorunlar insanların zamanlarını daha verimli kullanması bağlamında bir takım çalışmalar yapmalarını gerektirmiştir. Bu bağlamda bireyler çalışma zamanları dışında kalan dilimlerde fiziksel ve ruhsal açıdan yenilenme gereksinimlerini karşılamayı amaçlayarak farklı etkinlikler yapmaya başlamışlardır. İnsanların boş zaman dilimlerinde kendilerine vakit ayırmalarının, iş ortamlarında yaşadıkları stresten uzaklaşmaları ve sosyal yaşamlarına renk katmaları açısından katkı sağlamaktadır.

Bireylerin iş hayatları ve fizyolojik intiyaçlarının dışındaki kalan zaman dilimlerinde özgür iradelerini kullanarak gerçekleştirmiş oldukları etkinlikler rekreasyon kavramının içeriğini oluşturmaktadır. Rekreasyon etkinlikleri sayesinde bireyler hem yaşamlarında farklı faaliyetlere yönelmekte hem de psikolojik açıdan faydalar görmektedirler. Sosyal hayat içerisinde kullanılan doğal alanların sürdürülebilir bir nitelik kazanması hususunda yapılan çalışmaların artmasıyla birlikte insanlar doğal alanlara yönelik faaliyetlerinde daha bilinçli davranışlar sergilemeye yönelmişlerdir. 2000'li yıllarla birlikte çevreci gruplar oluşmaya başlamıştır. Bu gruplar doğal alanların tahribatının önlenmesine yönelik çeşitli faaliyetler gerçekleştirmişler ve bütün dünyada kitlelerini artırmaya başlamışlardır. Boş zamanlarını doğal alanlarda geçiren bireyler özellikle çevreci davranma konusunda hassas tutumlar sergilemektedirler. Dolayısıyla diğer insanların da bu konuda hassas olması gerektiğini düşünmektedirler. Ayrıca kamu kurum ve kuruluşları tarafından yine doğal alanların korunmasına yönelik bir dizi önlemler geliştirilmiştir (Özer vd., 2015; Tutar, 2015).

Rekreasyon faaliyetlerinin bir kısmını kapsayan turizm sektöründe çevre yanlısı çalışmalar yürütülmeye başlamış (yeşil yıldız uygulaması) ve doğaya verilen zararın minimize edilmesi veya tahribatın önlenmesi gibi tutumlar sektörde kullanılması gereken önemli kriterler haline gelmiştir. Tüketicilerin doğal alanların tahribatını önleyen ve toplumsal fayda sağlayacak şekilde uygulamalar gerçekleştiren (su ve elektrik tasarrufu, hayvan barınaklarına yiyecek gönderme vb.) işletmeleri tercih ettiklerine yönelik bulgular işletmelerin daha kapsamlı uygulamalarla hizmet vermeye başlamasını sağlamıştır (Gadenne vd., 2009; Flammer, 2013; Heiskanen, 2005). Çevre dostu uygulamaların oluşturulması konusunda henüz tam anlamıyla istenilen noktaya gelinmiş olmasa da daha iyi bir çevre ve bilinçli bir tüketici kitlesinin oluşturulması adına çalışmalar gerçekleştirilmeye devam etmektedir.

$\mathrm{Bu}$ araştırma, turizm sektöründe hizmet sağlayıcı olmaları beklenen, eğitim süreçlerini tamamladıklarında işletmelerde yöneticiliğe ve alanda eğitim vermeye aday olan turizm alanı öğrencilerini kapsamaktadır. Araştırmada öğrencilerin ekolojik farkındalıklarının çevre dostu rekreasyon davranışlarına etkisinin belirlenmesi amaçlanmaktadır. Zira gelecekte turizm sektöründe veya rekreasyon alanında söz sahibi olacak turizm mezunu öğrencilerin ekolojik farkındalıklarının verilen eğitimler veya mesleklerine bakış açıları kapsamında edinmiş oldukları deneyimler sonucu ne düzeyde olduğunun belirlenmesi önem arz etmektedir. Schleicher (1989) hazırladığı çalışmada özellikle çevreye yönelik eğitimlerin ekolojik farkındalığa etkisi olduğunu ifade etmektedir. Buradan hareketle Türkiye'de turizm eğitimi alan öğrencilerin ekolojik farkındalıklarının belirlenmesi eğitim sürecine de vurgu yapılabilmesi adına önemlidir. Araştırmanın ilerleyen kısımlarında araştırma modeli içerisinde yer alan değişkenlere yönelik literatür incelemesi, araştırmada kullanılan yöntem kapsamında elde edilen bulguların istatistiki analizler yardımıyla yorumlanması yer almaktadır. 


\section{Kuramsal Çerçeve}

\subsection{Ekolojik Farkındalık}

Toplumsal pazarlama anlayışının gelişimi ile beraber doğal alanların korunmasına yönelik yönetim ve pazarlama alanlarındaki uygulamalar turizm endüstrisinde hızla yayılmakta ve tüketiciler tarafından olumlu karşılanmaya başlamaktadır. Türkiye'de turizm sektöründe çevre bilincinin artmasına yönelik gerçekleştirilen yeşil yıldız uygulaması bu çalışmalara örnek olarak gösterilebilir. Dolayısıyla tüketicilerin doğayı koruma konusunda bildikleri veya doğada oldukları anda koruyucu tavırları sürdürülebilirlik açısından önemli görülmektedir. Kollmuss ve Agyeman (2002: 253) hazırlamış oldukları çalışmada ekolojik farkındalık teriminin önemini vurgulayarak, terimi; "insan davranışlarının çevre üzerindeki etkisinden haberdar olmak" şeklinde tanımlamaktadırlar. Ayrıca ekolojik farkındalık değişkeninin iki bileşenden oluştuğunu ve bu bileşenlerin ise bilgiye dayalı (bilişsel) ve hislere dayalı (duygusal) olarak açıklamaktadırlar.

Ekolojik farkındalığın bileşenlerinde olan bilişsel farkındalık sınırlamaları incelendiğinde; birçok ekolojik problemin hızlı gerçekleşmemesi (somut olarak görünemeyecek şekilde gerçekleşen çevre tahribatları ve bireylerin bu durumu fark edememesi), yavaş ve kademeli olarak gerçekleşen ekolojik tahribatlar ve karmaşık görünümlü çevresel sorunlar şeklindedir (Kollmuss ve Agyeman, 2002). Duygusal farkındalık sınırlamaları ise; ekolojik ilgisizlik ve ekolojik tepkidir (Chan vd., 2014: 21). Doğaya yönelik gerçekleştirilen rekreatif faaliyetlerde bulunmuş bireyler daha önce doğaya yönelik deneyimleri olmayan bireylere göre koruma çalışmaları bakımından sahip oldukları tutumların daha yüksek olduğu ifade edilebilir (Newhouse, 1991; Chawla, 1999). Dolayısıyla duygusal farkındalık oluşumunda deneyimin gücü önemli olmaktadır. Farkındalığın artması gerekliliği ve buna yönelik oluşan tepkilerde deneyimli bireyler duygusal farkındalıklarıyla hareket etmektedirler. Bilişsel ve duygusal bileşenlerin toplamını ifade eden ekolojik farkındalık kavramında deneyimler önemli olmaktadır. Örneğin turizm sektöründe çevreci ve geçmiş deneyimleri fazla olan turistler, konakladıkları otellerde kullanılan su ve enerji konularında daha duyarlı olacak şekilde planlamalar yapılıyor olması, yiyecek ve içeceklerde atıkların ayrıştııılarak hayvan barınaklarına gönderiliyor olması gibi önlemlere karşı daha pozitif düşüncelerde oldukları farklı çalışmalarca dile getirilmiştir (Han vd., 2009; Han vd., 2010; Han ve Kim, 2010; Özer vd., 2015). Ayrıca yine farklı çalışmalarda otel çalışanlarının tutumlarında ekolojik farkındalığın öneminden bahsedilmektedir (Chan ve Hawkins, 2010; Chan vd., 2014). Kement (2015) tarafından hazırlanan çalışmada kamp alanlarında yine tüketicilerin çevreye yönelik davranışlarının belirlenmesinde ekolojik tutum ve bazı çevreye yönelik değişkenlerin (ekolojik kaygı vb.) kullanıldığı ve elde edilen sonuçlarda ekolojik tutumlarının, davranışlarında önem arz ettiği sonucuna ulaşıımıştır. Tüm bu bilgiler doğrultusunda bu araştırmada, turizm eğitimi alan öğrencilerin ekolojik farkındalıklarının davranışlarına nasıl bir etkisi olduğunun incelenmesi amaçlanmıştır. Buna göre $\mathrm{H}_{1}$ kurulmuştur;

$\mathbf{H}_{1}$ : Araştırmaya katılanların ekolojik farkındalıkları çevre dostu rekreasyon davranışlarını olumlu yönde etkiler.

\section{2. Çevre Dostu Rekreasyon Davranışı}

Davranış canlının iç ve dış etkilere yönelik gösterdiği bilinçli tepki olarak ifade edilebilir. Buradan yola çıkarak davranışı "hareketten" ayıran nokta bilinçli olarak (refleks vb. şekilde olmaması) gerçekleşiyor olmasıdır (Georgel ve Jones, 1997). Psikolojik açıdan bakıldığında insan davranışları üç şekilde gerçekleşebilmektedir. Bunlar; duyma, 
algılama, bellekte saklama gibi bilişsel etkinlikler, bedence yapılan kassal diğer bir adıyla devinimsel etkinlikler ve duygu ve coşku içeren duygusal etkinliklerdir (Başaran, 2000: 15)

İnsan davranışlarını açıkladığı düşünülen etkinlikler doğaya yönelik gerçekleştirilen rekreatif etkinlikler açısından değerlendirildiğinde; bireylerin özellikle doğal alanlarda yapmış oldukları yürüyüşler, kamp faaliyetleri gibi etkinlikler devinimsel davranışlara örnektir. Ayrıca doğal alanların tahribatını önlemeye yönelik bir takım çalışmalar oluşturup sürdürülebilirliği sağlamaya yönelik yapılan etkinlikler bilişsel davranışa ve doğal alanlara yönelik duygusal açıdan var olan merak ve heyecan sonucu gerçekleştirilen etkinlikler de duygusal etkinliklere örnek olarak gösterilmektedir.

Doğaya yönelik gerçekleştirilen rekreatif etkinliklerde bireylerin özellikle somut halleriyle bir davranışta bulunmaları gerekmeyebilir. Bireylerin doğal alanları korumaya yönelik yapmış oldukları faaliyetler de (doğayı korumaya yönelik imza kampanyası, doğal alanların taşıma kapasitelerinin belirlenmesini destekleme, taşıma kapasitesi düşük olan alanların kullanıma kapatılması vb.) bir rekreasyon davranışı olarak nitelendirilebilir.

Davranışlar fizyolojik, psikolojik ve sosyolojik açılardan ele alınabilmektedir (Tutar, 2014; Güney, 2009; Silah, 2005; Aldag ve Fuller, 1993). Çevre dostu rekreasyon davranışı özü itibariyle fizyolojik ve sosyolojik olabileceği gibi psikolojik olarak da gerçekleşebilir. Dolayısıyla bireyler bir grubun yapacağı davranışlar itibariyle sosyolojik bir davranış gerçekleştirebileceği gibi duygusal olarak tahribattan etkilenmiş bir bireyin sert önlemler alınmasına yönelik tutum ve eğilimleri de psikolojik bir davranış göstergesi olarak açıklanmaktadır. Tüm bu bilgiler doğrultusunda çevre dostu rekreasyon davranışı; çevreye yönelik rekreatif etkinliklerde aktif olarak yer alan veya çevresel rekreatif aktivitelere yönelik psikolojik ve sosyolojik olarak eğilimlerde bulunan bireylerin çevre dostu davranışlar sergilemeleri şeklinde açıklanmaktadır.

Alan yazın incelendiğinde çevre dostu davranış değişkeni farklı araştırmacılar tarafından çalışmalarında kullanıımıştır (Nordlund ve Garvil, 2002; Thapa, 2010; Song vd., 2012; Zhang vd., 2014; Han ve Yoon, 2015). Özellikle Song vd., (2012) yürüttükleri çalışmada festival ziyaretçilerinin çevre dostu turizm davranışlarının, ziyaretçilerin isteklerine etkisini belirlemeyi amaçlamışlar ve sonuçlar incelendiğinde ilgili değişkenin ziyaretçilerin isteklerine etkisi olduğu sonucuna ulaşmışlardır. Ayrıca Kement ve Güçer (2015) tarafından hazırlanan çalışmada kamp alanlarında, ekolojik tutum ve rekreasyonel motivasyon değişkenlerinin çevre dostu rekreasyon davranışına etkisi incelenmiş ve çevre dostu rekreasyon davranışına ilgili değişkenlerin olumlu yönde etkisi olduğu belirlenmiştir. Literatürde yer alan bilgiler doğrultusunda bu çalışmada da çevre dostu rekreasyon davranışı belirlenmeye çalışılmaktadır. Araştırmanın amacı doğrultusunda ekolojik farkındalığın çevre dostu rekreasyon davranışına etkisi incelenmektedir. Ayrıca turizm eğitimi almakta olan öğrencilerin bölümleriyle ekolojik farkındalıkları ve çevre dostu rekreasyon davranışları arasında anlamlı bir farklılık olup olmadığı incelenmektedir.

\section{Araştırmanın Yöntemi}

\subsection{Evren ve Örneklem}

Bu araştırmanın amacı Türkiye'de üniversitelerde turizm eğitimi alan öğrencilerin ekolojik farkındalıklarının çevre dostu rekreasyon davranışlarına etkisinin 
belirlenmesidir. Dinler (1998)'e göre bu tür araştırmalar amaç ve düzey yönünden uygulama araştırmaları kapsamına girmektedir. Araştırmanın evrenini Türkiye'deki üniversitelere bağlı bulunan turizm fakülteleri, turizm ve otelcilik yüksekokulları ve turizm alanına yönelik olan meslek yüksekokullarında eğitim görmekte olan öğrenciler oluşturmaktadır. Türkiye'de ön lisans düzeyinde turizm eğitimi alan 43,447 öğrenci, lisans düzeyinde eğitim alan ise 24,191 öğrenci mevcuttur (OSYM, 2015). Araştırmada evrenin tamamına erişilmesi mümkün olmadığı için örneklem alma yoluna gidilmiştir. Rescoe (1975) ideal bir araştırmada örneklem hacminin 30 ile 500 arasında olmasının uygun olduğunu ifade etmektedir. Ayrıca birden fazla faktöre sahip çalışmalarda örneklemin ilgili faktörlerin on katı veya daha fazlası olacak şekilde alınmasıyla güvenilir sonuçlara ulaşılabileceğini ifade etmektedir. Bu kapsamda araştırmada kullanılan değişken sayısı da temel alınarak daha fazlasını içerecek şekilde kolayda örneklem yöntemiyle 284 katılımcıya anket uygulanmıştır. Anketler internet ortamından ve yüz yüze olarak farklı şekillerde toplanmıştır. Araştırma kapsamında elde edilen verilerin istatistiki programa işlenmesi sırasında bazı anketlerin boş veya eksik olarak doldurulduğu tespit edilmiş ve ilgili anketler araştırmadan çıkartılmıştır. Araştırmada istenilen amaca ulaşılması için eksik ve boş olan 28 anket çıkartılmış ve toplam 256 anket kullanılmıştır.

Araştırma kapsamında oluşturulan sorular, ilgili literatür taraması ve uzmanların görüşleri doğrultusunda belirlenmiştir. Ayrıca anket uygulanmadan önce 30 kişilik, turizm eğitimi almakta olan öğrencilere yapılmış, yanlış anlaşılan ve anlaşılmayan ifadeler düzeltilmiştir. Ayrıca araştırmada ekolojik farkındalığı ölçen 3. soru olumsuz ifade içerdiği için analiz aşamasında ters çevrilmiş ve bu bölümle ilgili yapılan analizler dönüşüm sonrası ortaya çıkan yeni değerler ile gerçekleştirilmiştir.

$\mathrm{Bu}$ araştırmada veri toplama aracı olarak kullanılan anket Han ve Yoon (2015)'un çalışmasından ve Kement (2015) tarafından yapılmış çalışmadan uyarlanmıştır. Araştırmada kullanılan ekolojik farkındalık soruları (EF1: Halk sağlının üzerinde kirliliğin etkileri düşünülenden daha fazladır, EF2: Önümüzdeki birkaç yıl içinde binlerce canlı türünün soyu yok olacak, EF3: Şu anki kirlilik seviyesinin dünyanın iklim şartlarını değiştirdiği iddiası abartıdır ve EF4: Ekolojik koruma (önlemler) hem benim hem de gelecek nesiller için daha iyi bir dünya sağlayacaktır) Han ve Yoon (2015) tarafından yürütülen çalışmadan alınmıştır. Sorular Türkçeye çevrilmiş ve sorularda çeviri esnasında anlam bozukluğu oluşup oluşmadığını belirlemek için tekrar İngilizceye çevrilerek sağlaması yapılmıştır. Çevre dostu rekreasyon davranışı soruları (ÇDRD1: Mümkün olduğunca çevreye yönelik rekreatif etkinliklerimde çevreye karşı duyarlı davranıyorum, ÇDRD2: Bireylerin hangi tür davranışlarının doğal çevreye etki ettiği hakkında fikir sahibiyim, ÇDRD3: Çevreye yönelik rekreatif etkinliklerimde davranışlarımın doğal çevreye etkisini minimize etmeye çalışıyorum, ÇDRD4: Rekreatif etkinliklerden/ turizm etkinliklerinden çoğunlukla doğaya yönelik rekreatif etkinlikleri/eko turizm faaliyetlerini tercih ederim) Kement (2015) tarafından hazırlanan çalışmadan alınmıştır. İlgili sorular araştırmanın amacına yönelik anlam açısından değişiklik olmayacak şekilde düzenlenmiştir. Söz konusu anket formu iki bölümden oluşmaktadır. Birinci bölümde katılımcıların demografik özelliklerine ilişkin sorular yer alırken, ikinci bölümde ekolojik farkındalık ve çevre dostu rekreasyon davranışı ölçeklerine ilişkin sorular bulunmaktadır. Ölçeklere ilişkin sorular 5'li likert ölçeğine uygun olarak sıralanmıştır.

\section{2. Ölçeklerin Güvenilirliği}

Araştırmada ölçekle elde edilen verilerin güvenilirliğini saptamak amacıyla Alpha Modeli ile güvenilirlik kat sayısı olan Cronbach Alpha kullanılmıştır. Crombach Alpha 
değerleri ankette yer alan her bir değişken için ayrı ayrı hesaplanmıştır. Yapılan inceleme sonucunda ekolojik farkındalık değişkenini ölçmekte olan dört sorunun güvenilirliği 0,73 , çevre dostu rekreasyon değişkenini ölçmekte olan dört sorunun güvenilirliği 0,74 olarak hesaplanmıştır. Bütün değişkenleri içeren genel güvenilirlik düzeyi ise 0,75 olarak belirlenmiştir. Bu araştırmada belirlenen ölçek güvenilirlikleri 0.70-0.80 arasında olan "ekolojik farkındalık" ve "çevre dostu rekreasyon davranışı" ölçekleri güvenilirlik açısından "iyi” olarak kabul edilmektedir (Hair vd., 2006).

\subsection{Tanımlayıcı İstatistikler}

Araştırmada ölçülmesi hedeflenen değişkenlerin ortalama, standart sapma, basıklık ve çarpıklık değerleri hesaplanmıştır. Bu değişkenlere ilişkin belirtilen değerler tabloda detaylı olarak verilmektedir.

\section{Tablo 1: Tanımlayıcı İstatistikler}

\begin{tabular}{|l|c|c|c|c|}
\hline Değişkenler & Ort. & Standart sapma & Çarpıklık & Basıklık \\
\hline Ekolojik Farkındalık & 4,45 & 0,556 & $-0,784$ & 0,238 \\
\hline Çevre Dostu Rekreasyon Davranışı & 4,22 & 0,58 & $-0,356$ & $-0,506$ \\
\hline
\end{tabular}

Tabloda verilen değişkenlerin çarpıklık ve basıklık değerleri \pm 3 arasındadır. Shao (2002)'ya göre çalışmada kullanılacak verilerin normal dağılım göstermesi, çarpıklık ve basıklık değerlerinin \pm 3 arasında olmasına bağlıdır. Dolayısıyla, veriler normal dağılım göstermektedir. Bu bilgiden hareketle, verilere regresyon, korelasyon gibi parametrik testler uygulanabilmektedir.

\section{Araştırma Bulguları}

\subsection{Demografik Bulgular}

Araştırmaya katılanların demografik özelliklerine ilişkin bilgiler incelendiğinde \%51,6'sının erkek, \%48,4'ünün bayan olduğu görülmektedir. Katılımcıların yaşa göre dağılımı incelendiğinde en çok katılımcının \%62,1 yüzdesi ile 18-22 yaş aralığı olduğu görülmektedir.

Tablo 2: Demografik Özelliklere İlişkin Frekans Analizi

\begin{tabular}{|l|l|c|c|}
\hline Demografik Değişkenler & & $\mathbf{n}$ & $\%$ \\
\hline \multirow{5}{*}{ Cinsiyet } & Bay & 132 & 51,6 \\
\cline { 2 - 4 } & Bayan & 124 & 48,4 \\
\hline \multirow{4}{*}{ Yaş } & $<18$ & 3 & 1,2 \\
\cline { 2 - 4 } & $18-22$ & 159 & 62,1 \\
\cline { 2 - 4 } & $23-26$ & 73 & 28,5 \\
\cline { 2 - 4 } & $27-34$ & 15 & 5,9 \\
\cline { 2 - 4 } Yüksek Öğrenim Düzeyi & $35 \leq$ & 6 & 2,3 \\
\hline \multirow{5}{*}{ Ön Lisans } & 55 & 21,5 \\
\cline { 2 - 4 } & Lisans & 201 & 78,5 \\
\hline \multirow{5}{*}{ Aile Gelir Durumu } & Rekreasyon Yönetimi & 33 & 12,9 \\
\cline { 2 - 4 } & Gastronomi ve Mutfak Sanatları & 54 & 21,1 \\
\cline { 2 - 4 } & Seyahat Işletmeciliği & 55 & 21,5 \\
\cline { 2 - 4 } & Turizm Işletmeciliği & 114 & 44,5 \\
\hline & $0-1300$ & 75 & 29,3 \\
\cline { 2 - 4 } & $1301-2600$ & 42,2 & 16,8 \\
\cline { 2 - 4 } & $2601-3900$ & 30 & 11,7 \\
\cline { 2 - 4 } & 3901 ve üzeri & & \\
\hline
\end{tabular}


Araştırmaya katılanların \%78,5'inin lisans düzeyinde eğitim aldığı, \%44,5'inin turizm işletmeciliği bölümünde eğitim gördüğü ve \%42,2'sinin 1301-2600 miktarında gelir durumuna sahip olduğu görülmektedir.

Ayrıca araştırmaya katılanların bölümleri ile ilgili kısımda; turizm alanında ön lisans düzeyinde eğitim gören öğrencilerden turizm ve otel işletmeciliği eğitimi alanlar, turizm işletmeciliği bölümüne, aşçılık eğitimi alanlar gastronomi ve mutfak sanatları bölümüne, seyahat ve eğlence hizmetleri ve turizm rehberliği eğitimi alan öğrenciler ise seyahat işletmeciliği bölümüne dâhil edilmişlerdir. Dolayısıyla ankette ön lisans okuyan öğrenciler için ayrı bir bölüm seçeneği oluşturulmamıştır.

\subsection{Doğrulayıcı Faktör Analizi: Ölçme Modelinin Testi}

Doğrulayıcı faktör analizi ölçme modeli ölçeğin geçerliliğini test etmek için kullanılmaktadır (Anderson ve Gerbing, 1988). İlgili ölçme modeli önceden oluşturulmuş bir model aracılığıyla gözlenen değişkenler yardımı ile gizil değişken oluşturmayı hedeflemektedir (Myers, 2000). Araştırmada ekolojik farkındalık ve çevre dostu rekreasyon davranışı değişkenleri ile oluşturulan ölçme modeli test edilmektedir. Böylelikle soru kâğıdındaki ifadelerin ölçülmek istenen değişkenleri ne derece açıkladığı belirlenmektedir. Dolayısıyla birinci düzey doğrulayıcı faktör analizi yapılmıştır.

Modelin kabul edilme durumu, analiz sonucu ortaya çıkan uyum istatistiklerinin belli değerlerin üzerinde veya altında olmasına bağlıdır (Gültekin, 2010). Araştırmada model uyumunun iyi olması için ki-karenin anlamsız çıkması gerekmektedir. Ancak, küçük örneklemlerde ki-kare genellikle anlamsız çıkarken, büyük örneklemlerde çoğunlukla anlamlı çıkmaktadır. Dolayısıyla ki-kare değeri serbestlik derecesine bölünerek $\left(\chi^{2} / d f\right)$ analiz gerçekleştirilmektedir. Yapılan analiz sonucunda değerin 5 'in altında olması ile modelin kabul edilebilir, 2'nin altında olması ise, modelin iyi bir uyuma sahip olduğu anlamına gelmektedir (Şimşek, 2007: 14). Ayrıca, uyum iyiliği indeksi (GFI) ve karşılaştırmalı uyum indeksinin (CFI); 0,90-1.00 arası değerler vermesi uyum iyiliğinin kabul edilebilir olduğu göstermektedir (Kline, 1998; Bryne, 2001). Uyum iyiliği istatistiklerinden yorumlama kolaylığı, güven aralığı sağlama ve örneklem büyüklüğünden bağımsız tahminler sağlama açısından Yaklaşık Hata Kare Kökü (Root Mean Square Error of Approximation-RMSEA) önem arz etmektedir (Şimşek, 2007: 47). RMSEA değerinin, 0.05 'in altında olması "iyi", 0,05 ile 0.08 arasında olması, "kabul edilebilir" uyum iyiliği değerini ortaya koymaktadır (Stevens, 2001; Schermelleh-Engel ve Moosbrugger, 2003).

Araştırma değişkenlerine ilişkin ölçme modelinin doğrulayıcı faktör analizinde örtük değişkenlerden (EF: ekolojik farkındalık değiş̧keninden, EF1, EF2, EF3 ve EF4'e, DAV: çevre dostu rekreasyon davranışı değişkeninden, DAV1, DAV2, DAV3 ve DAV4'e olacak şekilde) gözlenen değişkenlere doğru tanımlanmış olan yollara ilişkin standardize edilmiş parametre değerleri gösterilmektedir. 


\section{Şekil 1: Doğrulayıcı Faktör Analizi Sonuçları}

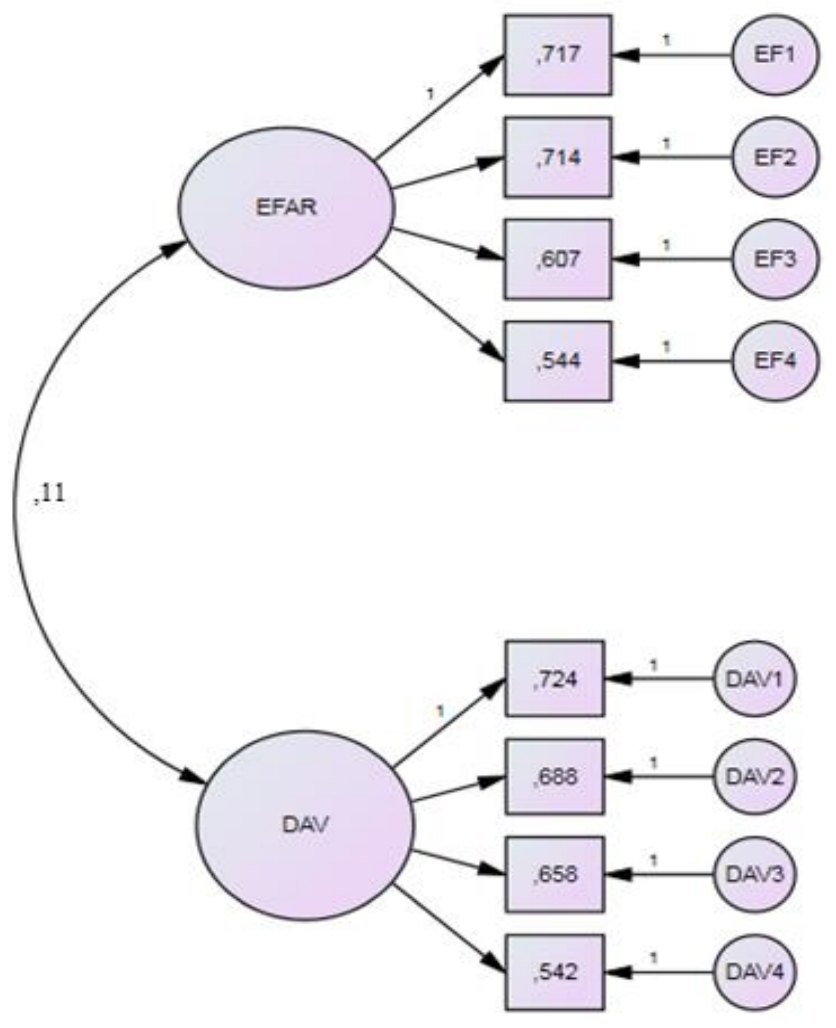

Şekilde AMOS grafik menüsü yardımıyla çizilen yol diyagramı yer almaktadır. Araştırmada standardize edilmiş değerlerin 1'in üzerinde olmaması beklenmektedir. 0,11 değeri EF ve DAV arasındaki standardize edilmiş korelasyon değerini göstermektedir. Standardize edilmiş çözümleme değerleri her bir maddenin (gözlenen değişkenin) kendi gizil değişkeninin ne kadar iyi bir temsilcisi olduğuna ilişkin fikir vermektedir (Hair vd., 1998; Şimşek, 2007; Aytaç ve Öngen, 2012). Yol diyagramına bakıldığında, gizil değişken olan EF ve DAV'tan gözlenen değişkene doğru yönelen tek yönlü oklar tek yönlü doğrusal ilişkiyi göstermektedir. Söz konusu değişkenler her bir maddenin kendi gizil değişkenini ne kadar iyi temsilcisi olduğuna ilişkin bilgi vermektedir (Aytaç ve Öngen, 2012). Şekilde yer alan, standardize edilmiş değerler incelendiğinde $E F$ faktörünü en fazla etkileyen boyut 0,717 'lik bir yükle "Halk sağlının üzerinde kirliliğin etkileri düşünülenden daha fazladır" sorusu ve en az etkileyen boyut ise 0,544 'lük bir yükle "Ekolojik koruma (önlemler) hem benim hem de gelecek nesiller için daha iyi bir dünya sağlayacaktır" sorularıdır. Diğer bir ifade ile halk sağlığının üzerinde kirliliğin etkilerinin oldukça fazla olduğuna yönelik yüksek bir algının, ekolojik korumanın gelecek ve bireylerin kendileri için daha iyi bir dünya sunacakları hususunun önem derecesine yönelik algının daha düşük olduğu ifade edilebilir.

DAV faktörünü en fazla etkileyen boyut 0,724 ile "Mümkün olduğunca çevreye yönelik rekreatif etkinliklerimde çevreye karşı duyarlı davranıyorum" sorusu olurken, en az etkileyen boyut 0,542 ile "Rekreatif etkinliklerden/ turizm etkinliklerinden çoğunlukla doğaya yönelik rekreatif etkinlikleri/eko turizm faaliyetlerini tercih ederim" sorusu olmuştur. Diğer bir ifade ile katılımcılar çevre dostu rekreasyon davranışlarında mümkün olduğunca çevreye duyarlı davrandıklarını yoğunlukla ifade ederken, rekreatif etkinliklerde çevreye yönelik aktiviteleri daha az tercih ettiklerini verdikleri yanıtlar neticesinde ifade etmektedirler. Toplam örneklem için oluşturulan modelim uyum 
indekslerine bakıldığında $\chi^{2} / d f \quad(1,888)$ değerinin 3'ün altında olması, GFI değerinin 0,96 olması kabul edilebilir bir uyum olduğunu, CFI değerinin 0,96 olması ve RMSEA değerinin 0,059 olması iyi bir uyum olduğunu göstermektedir. Sonuç olarak elde edilen bu uyum indeksleri modelin iyi ve kabul edilebilir bir uyuma sahip olduğunu açıklamaktadır.

Araştırmanın amacı doğrultusunda oluşturulan $\mathrm{H}_{1}$ hipotezinin açıklanması için regresyon analizi uygulanmıştır. Elde edilen sonuçlar tabloda detaylı olarak gösterilmektedir.

Tablo 3: Regresyon Analizi Sonuçları

\begin{tabular}{|c|c|c|c|c|c|c|c|}
\hline Değişken & B & Std. Hata & $\beta$ & $\mathbf{T}$ & $\mathbf{P}$ & \begin{tabular}{|l} 
Tolerans \\
\end{tabular} & VIF \\
\hline Sabit & 2,755 & 0,283 & & 9,724 & 0,000 & & \\
\hline EF & 0,330 & 0,063 & 0,311 & 5,222 & 0,000 & 1.000 & 1.000 \\
\hline $\mathrm{R}=, 311$ & $R^{2}=, 097$ & $\Delta \mathrm{R}^{2}=, 093$ & \multicolumn{3}{|c|}{ Durbin-Watson $=1,743$} & & \\
\hline$F_{(1,255)}=27$ & $p<0,000$ & & & & & & \\
\hline
\end{tabular}

Yapılan doğrusal regresyon analizi sonuçları incelendiğinde ekolojik farkındalık değişkeninin çevre dostu rekreasyon davranışı değişkeni üzerinde etkisi olduğu görülmektedir. Bu kapsamda ekolojik farkındalık $(p<0,01)$ ile çevre dostu rekreasyon davranışı arasındaki ilişki istatistiksel olarak anlamlı bulunmuştur. Çevre dostu rekreasyon davranışı ile ekolojik farkındalık arasında pozitif yönlü $(R: 0,311)$ bir ilişki vardır. Ayrıca belirlilik katsayısı $\left(R^{2}\right.$ : 0,097$)$ hesaplanmış olup, katılımcıların çevre dostu rekreasyon davranışlarındaki değişimin \%9,3'ünün modeldeki değişkenlere bağlı olduğu söylenebilir. Ayrıca katılımcıların ekolojik farkındalıklarındaki bir birimlik artış çevre dostu rekreasyon davranışlarında 0,311 birimlik artış sağlamaktadır. Dolayısıyla araştırma kapsamında oluşturulmuş " $H_{1}$ : Katılımcıların ekolojik farkındalıkları çevre dostu rekreasyon davranışlarını olumlu yönde etkiler” hipotezi kabul edilmiştir.

Araştırmada elde edilen sonuç, turizm eğitimi alan öğrencilerin çevre dostu rekreasyon davranışlarında ekolojik farkındalıklarının etkisinin olduğunu göstermektedir. Dolayısıyla turizm eğitimi alan öğrencilerin çevre dostu davranışlarının yaklaşık \%9'luk kısmının altında ekolojik farkındalıkları yatmaktadır. Geriye kalan $\% 91$ 'lik kısım ise başka nedenlerden kaynaklanmaktadır. Bu nedenler katılımcıların ekolojik bilgileri, kaygıları, rekreasyonel motivasyonları gibi birçok faktörden kaynaklanabilir. Bu nedenlerin ayrıca incelenmesi gerekmektedir.

Araştırmanın amacı doğrultusunda turizm eğitimi alan öğrencilerin bölümleri ile davranışları ve ekolojik farkındalıkları arasında anlamlı bir farklılık olup olmadığını belirlemek için Anova analizi yapılmıştır.

Tablo 4: Anova Analiz Sonuçları

\begin{tabular}{|l|l|l|}
\hline & F & Sig. \\
\hline EF & 2,324 &, 075 \\
\hline DAV & 7,965 &, 000 \\
\hline Homojenlik Testi Sonuçları: EF (sig.): ,034; DAV(sig.): 0,000 \\
\hline
\end{tabular}

${ }^{*} p: 0.05$

Yapılan Anova analizi sonuçları incelendiğinde turizm eğitimi alan öğrencilerin eğitim aldıkları bölümler ile çevre dostu rekreasyon davranışları arasında anlamlı bir 
farklııık olduğu görülürken, ekolojik farkındalıkları ile eğitim aldıkları bölümler arasında anlamlı bir farklılığın olmadı görülmektedir.

Elde edilen sonuçlar doğrultusunda öğrencilerin eğitim aldıkları bölümler ile çevre dostu rekreasyon davranışları arasındaki anlamlı farklıı̆ı̆ın hangisinden/hangilerinden kaynaklandığını belirlemek için homojenlik testi sonuçları doğrultusunda TUKEY HSD testi yapılmıştır (Akbulut, 2010). Elde edilen sonuçlar tabloda detaylı olarak gösterilmektedir.

Tablo 5: TUKEY HSD Analizi Sonuçları

\begin{tabular}{|c|c|c|c|c|}
\hline Bölümler (a) & Bölümler (b) & Farklılık (a-b) & S. Hata & Sig. \\
\hline \multirow{3}{*}{ Rekreasyon Yönetimi } & Gastronomi & ,00547 &, 12524 & 1,000 \\
\hline & Seyahat İşlet. &,- 02424 &, 12481 & ,997 \\
\hline & Turizm İşlet. &, $34051\left(^{*}\right)$ &, 11204 & ,014 \\
\hline \multirow{3}{*}{$\begin{array}{l}\text { Gastronomi ve Mutfak } \\
\text { Sanatları }\end{array}$} & Rekreasyon &,- 00547 & ,12524 & 1,000 \\
\hline & Seyahat İşlet. &,- 02971 & ,10858 & ,993 \\
\hline & Turizm Isslet. &, $33504\left(^{\star}\right)$ & 09363 &, 002 \\
\hline \multirow{3}{*}{$\begin{array}{l}\text { Seyahat İşletmeciliği ve } \\
\text { Rehberlik }\end{array}$} & Rekreasyon &, 02424 &, 12481 & ,997 \\
\hline & Gastronomi & 02971 &, 10858 & ,993 \\
\hline & Turizm İşlet. &, $36475\left(^{\star}\right)$ &, 09305 &, 001 \\
\hline \multirow{3}{*}{ Turizm İşletmeciliği } & Rekreasyon &,$- 34051\left(^{\star}\right)$ &, 11204 & .014 \\
\hline & Gastronomi &,$- 33504\left(^{*}\right)$ &, 09363 &, 002 \\
\hline & Seyahat İşlet. &,$- 36475\left(^{*}\right)$ &, 09305 &, 001 \\
\hline
\end{tabular}

Tabloda çevre dostu rekreasyon davranışı ve araştırmaya katılan turizm öğrencilerinin eğitim gördükleri bölümler arasındaki anlamlı farklııkların hangisi/hangileri arasında olduğunu belirlemek amacıyla yapılan Tukey HSD sonuçları verilmektedir. Elde edilen sonuçlar incelendiğinde rekreasyon yönetimi eğitimi alan öğrenciler ile turizm işletmeciliği bölümünde eğitim alan öğrencileri arasında anlamlı bir farklılığın olduğu görülmektedir. Rekreasyon yönetimi eğitimi alan öğrencilerin $\left(, 34051^{*}\right)$ turizm işletmeciliği eğitimi alan öğrencilerden daha fazla çevre dostu davranışlar sergilediği sonucuna ulaşılmıştır. Gastronomi ve mutfak sanatları eğitimi alan öğrencilerin $\left(, 33504^{*}\right)$ yine turizm işletmeciliği eğitimi alan öğrencilerden çevreye yönelik daha duyarlı olduğu, seyahat işletmeciliği ve turizm rehberliği eğitimi alan öğrencilerin $\left(, 36475^{*}\right)$ ise turizm işletmeciliği eğitimi alan öğrencilerden rekreatif aktivitelerde çevreye daha duyarlı oldukları tespit edilmiştir. Tüm bu bilgiler ışığında rekreasyon yönetimi, gastronomi ve mutfak sanatları ve seyahat işletmeciliği bölümlerinde okuyan öğrencilerin turizm işletmeciliği okuyan öğrencilerden çevre dostu rekreasyon davranışlarının daha fazla olduğu yorumu yapılabilir. Bu durumun nedenlerine bakıldığında özellikle rekreasyon ve seyahat işletmeciliği eğitimi alan öğrencilerin çevreyle yoğundan ilgili olmaları gösterilebilir. Zira rekreasyon alanı özü itibariyle toplumda sağlıklı olan insanların faydalarına ilişkin faaliyetleri destekleyen bir alan iken, seyahat işletmeciliği alanında eğitim alan öğrencilerin de doğal, tarihi ve kültürel alanların kültürel miras açıdan önemini detaylı olarak benimsemektedirler. Ayrıca gastronomi alanında eğitim alan öğrencilerin kullanılan yiyecek ve içeceklerde yine doğanın önemini işliyor olmaları, insan sağlığı için önem arz eden noktaları eğitim alanlarında görmeleri bu algı ve davranış farklılığına bir neden olarak gösterilebilir.

\section{Sonuç ve Tartışma}

Araştırmada elde edilen sonuçlar turizm alanında eğitim görmekte olan öğrencilerin çevreye yönelik farkındalıklarının yüksek olduğunu ve bu durumun da çevreyi 
korumaya ve tahribatları önlemeye yönelik davranışlarına olumlu yönde etki ettiğini göstermektedir. Gelecekte turizm sektöründe çalışan, yönetici gibi bir takım sorumlulukları alacağı düşünülen turizm öğrencilerinin bu noktada olumlu davranışlara sahip olmaları gelecekte turistik ve rekreatif alanlarda sürdürülebilir çevrenin oluşturulması noktasına katkı sağlayacakları ifade edilebilir. Çevre bilincinin turizm eğitimi verilen okullarda daha da artırılması yine gerekli olarak düşünülebilir. Zira elde edilen sonuçlar her ne kadar olumlu görünse de süreçte kalıcı koruyucu ve önleyici bir bilincin oluşturulmasında yine turizm ve rekreasyon alanlarının çevre ile ilişkisinin derinlemesine işlenmesinde fayda vardır.

Araştırma sonuçlarından bir diğerinde turizm öğrencilerinin çevre dostu rekreasyon davranışlarıyla okumuş oldukları bölümler arasında anlamlı farklılıklara ulaşılmıştır. Rekreasyon, gastronomi ve seyahat işletmeciliği eğitimi alan öğrenciler ile turizm işletmeciliği eğitimi alan öğrenciler arasında anlamlı bir farklılık elde edilmiştir. Araştırmada kullanılan örneklem sayısının sınırlı olması bu sonucun oluşmasına etki ettiği düşünülebilir. Ayrıca Türkiye'de rekreasyon ve gastronomi bölümlerinin üniversitelerde henüz yeterli sayıda olmaması örneklemin hemen hemen yarısının turizm işletmeciliği öğrencilerinden oluşmasına ve bu durumun da sonucu etkilemesine neden olmaktadır. Örneklemin farklı bölümler bazında olabilmesi için örneklem sayısı daha fazla artırımamıştır. Zira turizm işletmeciliği eğitimi alan öğrenci sayısına nazaran rekreasyon ve gastronomi eğitimi alan öğrenci sayısı çok azdır. Türkiye'de rekreasyon ve gastronomi eğitimi alan toplam öğrenci sayısının hemen hemen çoğunluğu araştırmaya dahil edilmiştir.

Han ve Yoon (2015) hazırladıkları çalışmada, Amerika'da yer alan konaklama işletmelerini ziyaret eden tüketicilerin ekolojik farkındalıklarının çevre dostu rekreasyon davranışlarını etkilediği sonucuna ulaşmışlardır. Araştırma Han ve Yoon (2015) tarafından yapılan çalışma ile aynı doğrultuda değerlere sahiptir. Ayrıca Kement ve Güçer (2015) tarafından yapılan ve kamp yapan tüketicilerin çevre dostu davranışlarının altında ekolojik tutum gibi değişkenlerin yer aldığı sonucuna ulaşılan çalışma ile sonuçlar örtüşmektedir. Özden (2008) çalışmasında öğrencilerin ekolojik farkındalıklarını ölçmeyi hedeflemiştir. Bu araştırmada elde edilen sonuçlar Özden (2008)'un çalışması ile paralellik göstermektedir. Wong (2003) yapmış olduğu çalışmada yine üniversite öğrencilerinin ekolojik farkındalıklarını incelemiştir. Sonuçlar incelendiğinde bu araştırmada da olduğu gibi genç kesimin ekolojik farkındalığının yüksek olduğu tespit edilmiştir. Korhonen ve Lappalainen (2004) yapmış oldukları çalışmada Madagaskar'da yaşayan gençlerin ekolojik farkındalıklarını, bilgilerini ve kaygılarını incelemişlerdir. Yazarların elde ettiği sonuçlara göre gençlerin ekolojik farkındalıkları yüksek çıkmıştır. Bulgular bu araştırmada elde edilen sonuçla aynı doğrultudadır. Ancak bu araştırmada turizm eğitimi alan öğrenciler evreni oluştururken yazarlar Madagaskar'da yaşayan bütün gençleri evrene dâhil etmişlerdir. Türkiye'de turizm eğitimi alan öğrencilerin ekolojik kaygıları Madagaskar'da yaşayan gençlerle mukayese edildiğinde yaklaşık olarak aynı çıkmıştır. Türkiye'de turizm eğitimi alan öğrencilerden beklenen ekolojik farkındalık düzeyinin yüksek çıkmasıydı. Bu beklenti her ne kadar karşılanmış olsa da Madagaskar'da yaşayan ve turizm eğitimi almamış veya alanların karışık olarak evreni oluşturduğu sonuçların bu araştırmanın sonuçları ile aynı çıkması Madagaskar'da çevre bilincinin özellikle gençler üzerinde daha fazla olduğunu gösterdiği söylenebilir.

Araştırma sonuçları incelendiğinde katılımcıların çevre dostu davranışlarının sadece \%10'luk kısmı ekolojik farkındalıktan kaynaklanmaktadır. Dolayısıyla bundan sonraki çalışmalarda katılımcıların çevre dostu davranmalarının diğer nedenleri araştırılmalıdır. 
Turizm sektöründe ve turizm alanı kamu kurum ve kuruluşlarında çevre dostu faaliyetlerin artması ile birlikte turizm alanında eğitim görmekte olan öğrencilerin de eğitimleri sürecinde gördükleriyle beraber çevre dostu davranışları ve farkındalıkları artmaktadır (Çakmak ve Özkan, 2016). Ayrıca gelecek zaman dilimlerinde daha fazla katılımcı ile ve yıllar itibariyle yapılabilecek bir araştırmada öğrencilerin yıllar itibariyle düşünce farklılıkları ve düşüncelerindeki değişimler irdelenebilir. Bu araştırmada öğrencilerin çevre dostu rekreasyon davranışlarının \%9'luk kısmını açıkladığı düşünülen farkındalık değişkeni dışından ilerleyen zamanlarda farklı değişkenler de kullanılarak yine öğrencilerin çevre dostu rekreasyon davranışlarının altında yatan etmenler derinlemesine belirlenebilir. Rekreasyon faaliyetleri bu araştırmada örnekler halinde öğrencilere sunulmamıştır. Öğrencilerin ekolojik farkındalıkları kapsamında çevre dostu rekreasyon davranışlarını geçmişte veya bugün yapmış/yapıyor oldukları düşünülmüştür. Bu araştırmadan yola çıkarak öğrencilerin çevre dostu rekreasyon davranışlarının ölçülmesinde çevreye yönelik rekreatif etkinlikleri dikkate alınarak ayrıca bir çalışma gerçekleştirilebilir ve bu sayede öğrencilerin gerçekten ifade ettikleri gibi mi davrandıkları da tespit edilebilir.

\section{Kaynakça}

Aldag, R. J. ve Fuller, S. R. (1993), "Beyond Fiasco: A Reappraisal of The Group Think Phenomenon and A New Model of Group Decision Processes", Psychological Bulletin, 113(3), ss. 533-552.

Anderson, J. C. ve Gerbing, D. W. (1988), "Structural E4quation Modeling in Practice: A Review and Recommended Two-step Approach", Psychological Bulletin, 103(3), ss. 411-423.

Akbulut, Y. (2010). Sosyal bilimlerde SPSS uygulamaları. İdeal Kültür Yayıncılık, İstanbul.

Aytaç, M. ve Öngen, B. (2012), "Doğrulayıcı faktör analizi ile Yeni Çevresel Paradigma Ölçeğinin yapı geçerliliğinin incelenmesi”, Istatistikçiler Dergisi, 5(1), ss. 14-22.

Başaran, İ. E. (2000). Örgütsel Davranış, Insanın Üretim Gücü. Feryal Matbaası, Ankara.

Byrne, B. M. (2001), "Structural Equation Modeling with AMOS, EQS, and LISREL: Comparative Approaches to Testing For the Factorial Validity of a Measuring Instrument", International Journal of Testing, 1(1), ss. 55-86.

Chan, E. S. W. ve Hawkins, R. (2010), "Attitude Toward Semss in an International Hotel: An Exploratory Case Study", International Journal of Hospitality Management, 29(4), ss. 641-651.

Chan, E. S. W., H. Alice. H., Chan, W. ve Okumuş, F. (2014), "What Drives Employees' Intentions to Implement Green Practices In Hotels? The Role of Knowledge, Awareness, Concern and Ecological Behaviour", International Journal of Hospitality Management, 40, ss. 20-28.

Chawla, L. (1999), "Life Paths into Effective Environmental Action", The Journal of Environmental Education, 31(1), ss. 15-26.

Clark, M., Riley, M., Wilkie, E., ve Wood, R. C. (1998). Research in Gand Writing Dissertations in Tourism and Hospitality, International Thomson Business Press.

Çakmak, A. Ç. ve Özkan, B. (2016), "Üniversite Öğrencilerinin Ekolojik Farkındalıkları İle Yeşil Tüketim Alışkanlıklarının Farklı Değişkenler Perspektifinden Karşılaştırılması: İnteraktif Bir Uygulama", Insan ve Toplum Bilimleri Araştırmaları Dergisi, 5(8), ss. 3144-3170.

Dinler, Z. (1998). Bilimsel Araştırma ve Internet'e Bağıı Bilgi Merkezleri El Kitabı, Ekin Kitapevi Yayınları, Bursa. 
Flammer, C. (2013), "Corporate Social Responsibility and Shareholder Reaction: The Environmental Awareness of Investors", Academy of Management Journal, 56(3), ss. 758-781.

Gadenne, D. L., Kennedy, J. ve Mckeiver, C. (2009), "An Empirical Study of Environmental Awareness and Practices in Smes", Journal of Business Ethics, 84(1), ss. 45-63.

Georgel, J., M. ve Jones, G. R. (1997), "Experiencing Work: Values, Attitudes, Andmoods", Human Relations, 50(4), ss. 393-416.

Gültekin, B. (2010), Faydacı-Hedonik Güdüler, Göz Atma Ve Marka Bilinirliğinin Anlık Alışverişe Etkisine İlişkin Bir Model Önerisi, Yayınlanmamış Doktora Tezi, İşletme Ana Bilim Dalı, Sosyal Bilimler Enstitüsü, Hacettepe Üniversitesi, Ankara.

Güney, S. (2009). Sosyal Psikoloji, Nobel Yayınları, Ankara.

Hair, J. F., Black, W. C., Babin, B. J., Anderson, R. E. ve Tatham, R. L. (2006). Multivariate Data Analysis, Pearson Prentice Hall, New Jersey, USA.

Han, H., Hsu, L., Tzang, J. ve Sheu, C. (2010), "Application Of The Theory of Planned Behavior to Green Hotel Choice: Testing the Effect of Environmental Friendly Activities", Tourism Management, 31(3), ss. 325-334.

Han, H., Hsu, L., Tzang J. ve Lee, J. (2009), "Empirical Investigation of The Roles of Attitudes Toward Green Behaviors, Overall Image, Gender and Age in Hotel Customers' Eco-Friendly Decision-Making Process", International Journal of Hospitality Management, 28(4), ss. 519-528.

Han, H.. Vekim, Y. (2010), "An Investigation of Green Hotel Customers' Decision Formation: Developing An Extended Model Of The Theory of Planned Behavior", International Journal of Hospitality Management, 29(4), ss. 659-668.

Han, H. ve Yoon, H. (2015), "Hotel Customers' Environmentally Responsible Behavioral Intention: Impact of Key Constructs On Decision in Green Consumerism", International Journal of Hospitality Management, 45, ss. 22-33.

Heiskanen, E. (2005), "The Performative Nature of Consumer Research: Consumers' Environmental Awareness As An Example", Journal of Consumer Policy, 28(2), ss. 179-201.

Kement, Ü. (2015), Doğaya Yönelik Gerçekleştirilen Rekreatif Etkinliklerde Tüketicilerin Çevre Dostu Rekreasyon Davranışlarının İncelenmesi: Kamping Örneği, Yayınlanmamış Doktora Tezi, Rekreasyon Yönetimi Ana Bilim Dalı, Sosyal Bilimler Enstitüsü, Gazi Üniversitesi, Ankara.

Kement, Ü. ve Güçer, E. (2015), "Kamping Yapan Bireylerin Çevre Dostu Rekreasyon Davranışlarına Ekolojik Tutum ve Rekreasyonel Motivasyon Değişkenlerinin Etkisinin İncelenmesi", Journal of Recreation \& Tourism Research, 2(3), ss. 1627.

Kline, R. B. (1998), "Software Review: Software Programs for Structural Equation Modeling: Amos, EQS and Lisrel, Journal of Psycho Educational Assessment, 16(4), ss. 343-364.

Kollmuss, A. ve Agyeman, J. (2002), "Mindthegap: Why Do People Act Environmentally and What are the Barriers to Pro-Environmental Behavior?", Environmental Education Research, 8(3), ss. 239-260.

Korhonen, K. ve Lappalainen, A. (2004), "Examining the Environmental Awareness of Children and Adolescents in The Ranomafana Region, Madagascar", Environmental Education Research, 10(2), ss. 195-216.

Myers, W. H. (2000). A Structural Equation Model of Family Factors Associated With Adolescent Depression, Dissertation Abstracts International: Section B: The Sciences and Engineering, 61(3-B). 
Newhouse, N. (1991), "Implications of Attitude and Behavior Research for Environmental Conser- Vation", The Journal of Environmental Education, 22(1), ss. 26-32.

Nordlund, A. M. ve Garvill, J. (2002), "Value Structures Behind Proenvironmental Behavior", Environment and Behavior, 34(6), ss. 740-756.

ÖSYM (Öğrenci Seçme ve Yerleştirme Merkezi) (2015), "Lisanslarda Bölümler Düzeyinde Öğrenci Sayıları", http://www.osym.gov.tr/Eklenti/4580,17 lisansfoetpdf.pdf?0, (02.01.2015).

ÖSYM (Öğrenci Seçme ve Yerleştirme Merkezi) (2015), "Ön Lisanslarda Bölümler Düzeyinde Öğrenci Sayıları", http://www.osym.gov.tr/Eklenti/4584,19onlisansfoetpdf.pdf?0, (02.01.2015).

Özden, M. (2008), "Environmental Awareness and Attitudes of Student Teachers: An Empirical Research", International Research in Geographical and Environmental Education, 17(1), ss. 40-55.

Özer, L., Kement, Ü. ve Gültekin, B. (2015), "Genişletilmiş Planlanmış Davranış Teorisi Kapsamında Yeşil Yıldızı ıtelleri Tekrar Ziyaret Etme Niyeti”, Hacettepe Üniversitesi Iktisadi ve Idari Bilimler Fakültesi Dergisi, 33(4), ss. 59-85.

Rescoe, J. T. (1975). Fundemantal Research Statistics for The Behavioural Sciences, Holt Rinehart and Winston, New York.

Schermelleh-Engel. K., Moosbrugger, H. ve Müller, H. (2003), "Evaluating The Fit of Structural Equation Models: Tests of Significance and Descriptive Goodness-ofFit Measures, Methods of Psychological Research Online, 8(2), ss. 23-74.

Schleicher, K. (1989), "Beyond Environmental Education: The Need For Ecological Awareness", International Review of Education, 35(3), ss. 257-281.

Shao, A. T. (2002). Marketing Research: An Aid to Decision Making, Cincinnati, Ohio: South-Western/Thomson Learning.

Silah, M. (2005). Sosyal Psikoloji: Davranış Bilimi, Seçkin Yayıncılık, Ankara.

Song, H. J., Lee, C. K., Kang, S. K. ve Boo, S. J. (2012), "The Effect of Environmentally Friendly Perceptions on Festival Visitors' Decision-Making Process Using An Extended Model of Goal-Directed Behavior", Tourism Management, 33(6), ss. 1417-1428.

Stevens, J. P. (2012). Applied Multivariate Statistics for The Social Sciences, Routledge, London, England.

Şimşek, Ö. F. (2007). Yapısal Eşitlik Modellemesine Giriş: Temel IIlkeler Ve Lisrel Uygulamaları, Ekinoks Yayınları, Ankara.

Thapa, B. (2010), "The Mediation Effect of Outdoor Recreation Participation on Environmental Attitude-Behavior Correspondence", The Journal of Environmental Education, 41(3), ss. 133-150.

Tutar, F. K. (2015), "Yeşil Ekonomi, Yeşil Turizm: Türkiye'de Turizm Sektöründe Yeni Trend Yeşillenen Oteller Projesi", Akademik Sosyal Araştırmalar Dergisi, 3(13), ss. 328-352.

Tutar, H. (2014). Sosyal Psikoloji Kavramlar ve Kuramlar, 2. Baskı, Seçkin Yayıncılık, Ankara.

Wong, K. K. (2003), "The Environmental Awareness of University Students in Beijing, China", Journal of Contemporary China, 12(36), ss. 519-536.

Zhang, Y., Zhang, H. L., Zhang, J. ve Cheng, S. (2014), "Predicting Residents' ProEnvironmental Behaviors at Tourist Sites: The Role of Awareness of Disaster's Consequences, Values, and Place Attachment", Journal of Environmental Psychology, 40, ss. 131-146. 